\title{
The Potential for Human Resources Development in APEC: Issues, Conflicts and Countermeasures
}

\author{
BYONG-SLH KIM \\ Diparmem of Sociolog;, Euha Womanj Uiriversity
}

The article foctuses on the potential for Human Resources Deselopment (HRD) of the Asia-Pacific Economic Cooperation (APEC) to make significant contributions to the conomic and political development in the Asia-Pacific region. The article seatrhes for countermeasures, which muly be prouided by the activities of the 1HRD programi and projects. Three major issues which are sourres of conflicas faced by $A P E C$ are nuted and andlyzect the issues of diversity of member economies and pouer imbalanse; the issue of agrement for the proposed $2010 / 2020$ Wheralization of the market by APEC countrits; and the issues related to sectsity. More than any other unit of $A P E C$, the $H R D$ unit with its variow projects, programs and Task Force activities has great potential

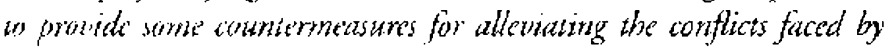
APICE Especially, HRD's Neturerk for Liducation Forum (EdFor) with ziarious projects surb as AELI, EduNet, Youth Vocational Trining way be able to generate mutunl understanding through effective communication of information and exchange of ideds and skills for social and economical denelopment. The assk force fur fical crisis along with the werisus HRD's neworks on induirrial and econnic developmeni(BMN, HLRDIT: LMI, NEDM has great potential to make signiffumt comtribution to alleviate the curent economic crisis in Ajin.

\footnotetext{
- Originally presuntei at the luternariona Conference, hosted hy the Insciture for International Trade: and

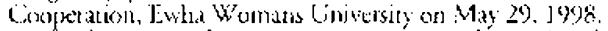

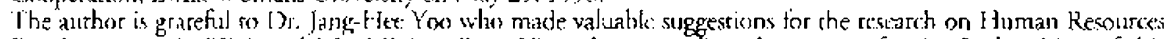
Developmen of API: $\therefore$ and Mr. Minkyu Beter Kim who gave edformal assistance for the final revision of this articte.

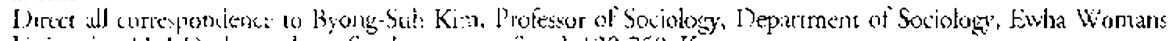
linvessin, 11-1 [ Jath;un-dong. Serdacmun-gu, Scoul, 120-750, Korea.
} 
$T$ he Asia-Pacific region in the twenty-first century with its trend of globalization and regionalism will surely the characterized by challenges of political economy. In this paper, I will first identify and analyze three major issues and conflicts faced by the Asia Pacific Economic Cooperation (Al'EC), and secondly, search for countermeasures which may reduce the conflicts and dilcrmmas with the help of APEC's I Iuman Resources Levelopment Unic. My assessment is that unless the issues and conflicts faced by APFC. are analyzed and reduced, it will be very difficult for APEC to he effective in contributing towards economic development, especially in the less developed member countries is Asia. Human Resources Development (HRD) activities do not necessarily deal with the issues of APLC. nor the economic crises faced by most of the Asian member conomicas. But I will argue that HRD has the potential to resolve APEC issues and can help the less developed rumber economies in the Asia-Pacific region.

\section{APEC AND THE HUMAN RESOURCES DEVELOPMENT UNIT}

Let me first describe the structure of Al'EC and the human resources development unit in the map of APEC. APrC is a unique economic and political organization which includes most of the major economies in the Asia-Pacific region. APEC, was formed in 1989 in response to the growing interdependence among Asia-Pacific economies. It was the year that the Coid War ended, as the USSR and the Eascern Furopean communist bloc began crumbling. Al'EC started as an informal dialogue group with limited participation, and became the fastest growing regional economic cooperative group in the world. Al'FC in 1997 had eighteen member countries: Australia, Brunei Darussalam, Canada, Chice, the Pcople's Republic of China, Hong Kong, Indonesia, Japan, Republic of Korea, Malaysia, Mexico, New 7.ealand, Papua New Guinea, Republic of the Philippines. Singapore, Chinese "Taipei, Thailand, and the United States. A host of other nations located in the region are waiting to become members."

Until the recent oconomic crisis, these eighteen member countries have boen making contributions to global prosperity and rapid cconomic development. They had a combined Gross Demestic Product of over US\$13 trillion in 1995, approximately 55 percent of the total world income and 46 percent of global trade. The share of APEC member economies in total world merchandise trade rose from under 32 percent in 1980 to almost 41 percent in 1992. More than 80 percent of the increase of the APEC member economies' share was due to the increased importance of Asian countries in the global economy. In 1992, rotal trade of Asian Al'EC member conomies accounted for 21.5 percent of world trade, compared to the 19.4 percent share of non-Asian ABEC menter conornics.

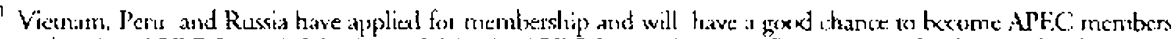
at the 1998 APEC. Summit Meering in Makaysia. APFC. Secretariat, 1997 Repurt, p.1.: for the menthership issue,

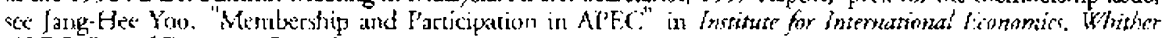
APEC? S̈pecisl Repors 9. Oa. 1997.

Al'FC. Stcrelariat, ig9? Rep̧ort. p.I.
} 
The objectives of APEC were agreed upon by the member economies. They are:

(1) to sustain the growth and devclopment of the region for the common good of its peoples and, it this way, to contribute to the growth and development of the world coonomy;

(2) 10 enhunce positive gains, both for the region and the workd econony, resulting from increasing conomic interdependence, to encourage the flow of gereds, services, captal, and technology:

(3) to develop and strengthen the apen multilatcral rrading system in the interest of the AsianPacitic and all other conomies; and

(4) to keduce barries to trade in goods and scrvices anong participants in a manner consisten with CATI principles, where applicable, and without decriment to other econtemies."

On the basis of these objectives, APEC sct up the Human Resources Development unit as one of the ten working groups. The Human Resources Development Working group, established in 1990 , managed about 70 projects."

It is composed of five sub-groups. The Busines: Management Network(BMN) focuses on executive educacion and development and management for organizational change. The Industrial Technology Network (LRDIT) is involved with technical and profession. al standards and indentification of skills shorrages. The Network for Fconomic Development Management (NFI)Mj looks at the regional labor market, small and medium enterprises, environment, gender and equity issues, and the use of human resources in economic development. 'T he Education Forum (EOFOR) concentrates on the performance of education swsems in preparing people for the rapidty changing labor market. The Labor Marker Intormation Croup (I.MI) serves as a torum for the exchange of information on labor matket trends in AIPEC.:.

All of these networks are tormed on the basis that the people in the region are its most important resures. Human resonices development is indeed contral to achieving sustained economic growth in any sociecy. It is also a key developmental policy in enhancing a continued flow of regional erade and investment. The development and protection of human resources contribure to the atrainment of such fundanental values as the alleviation of poverty, fill employment, universal access to primary, secondary and vocational eduation. and full participation of all groups in the process of conomic growth and development. AIPC atcempts to fulfill these goats by implenenting specific plans for $\mathrm{H}$ RL). It is, however, difficult for APEC, to achieve these goals unless some issues and conflict of interest among the member economics are clarificd and countermeasures are provided.

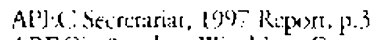

APEC s 9 other Wutking Grolips are: Fisheries, Industrial Sciense and Tectnology, Marine Resource

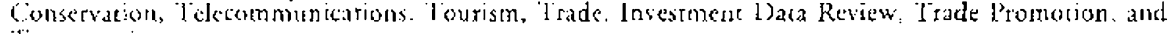
jearsportation.

Apt:C Socfetariak ] g以6 Rigun, p.8. 


\section{ISSUES AND CONFLICTS AMONG THE APEC MEMBER ECONOMIES}

There are three major issues which are sources of conflict for APEC: diversity in terms of the size of population and territory, national wealth, cultural traditions and historical experiences; the issue of agreement for $2010 / 2020$ for complete libcralizacion of the market, and the issue of security, which is a major concern for the United States.

\section{Issues of Diversity and Power Imbalance among the APEC Member Economies}

The current APEC member economies represent diversity with differing levels of economic growth, size of population and territory, contrasting cultural traditions with different historical experiences and compering political interests. The current $18 \mathrm{APEC}$ member economies have nos shared sense of identity, as shown in (Table 1). The diversity of the APEC member economies makes it difficulr to produce economic integrarion, while the success and the expanding size of its members tend to exacerbate conflicts of interest. Unlike the regionalization of Western Europe and North America, Asian economies of APEC tend to be closed to one another in terms of exports, political, and ideological matcers. Mutual political interests such as security seem wo be totally absent, and, in fact. AP'EC cxplicitly cook out any political itcms from its agenda. In particular, the three dominant powers of APEC --. i.e., the United States, Japan and China -- are divided among thenselves politically, and are eager to pursue their own national economic interests withour assuming a leadership role in helping APEC to become a more powerful institution in the new world order.

Prime Minister Mahathir Mohamad of Malaysia alluded that APEC inevitably would be dominated by the larger member economies, especially the United Srates. Prime Mitrister Mahathir's boycort of the Blake Island Meeting in Seattle sent a clear message of warning to the stronger economies to nor dominate the APEC and to not weaken such regional organizarions of Asia such as The Associarion of Southeast Asian Nations (ASEAN) and East Asian Econornic Caucus (EAEC). He stongly advocated a unified effort among Asian economies to avoid the dominance of the Anglo Saxon nations. Although Mahathir did not, or could not, grasp the realism of power politics, and had to quict his lone dissenting voice, he received syrnpathetic attention from the smaller member economies of APEC and ASFAN, albeir not openly."

\footnotetext{
"The Maldysian Prime Misister Malathir Mohamad stongly blamed the internartionat currency dealers of the advanced counuies who explusied the current econotnic crisis at the 1997 boonnice Leaders Mecring hold in Vancouver. Camada. President CYinton commented that Mahathir's statement was "nhantre." Summary of the Morning Sessions for APIC leaders Maeting, 3-5 \{ret. Korean Version).
} 


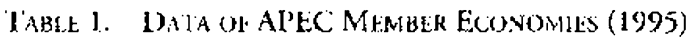

\begin{tabular}{|c|c|c|c|c|c|c|}
\hline APFC member & Population & Area & GNP/GDP & GNPpc/GDPPc & Fxport & Import \\
\hline Rustralia & 18.05 & 7.713 & 337,909 & 18.720 & 53.1 & 61.3 \\
\hline Brumei D) & 0.28 & 5.7 & (J) 4,496 & (1) $) 17,039$ & 2.4 & 2.1 \\
\hline Callada & 29.61 & $9,9 ? 6$ & 573.605 & 10,380 & I) 2.2 & 168.4 \\
\hline Chils & 4.22 & 747 & 59.151 & 4.160 & 16.0 & 15.9 \\
\hline I'R China & 1.200 .24 & 9,631 & 744.890 & 620 & 148.8 & 132.1 \\
\hline Houng Kong & 6.19 & 1.1 & (L) 142,332 & D) 22.990 & 173.9 & 196.1 \\
\hline lindoussial & 193.28 & 1,905 & 190,105 & 980 & 45.4 & 40.9 \\
\hline$J_{: 1|, 3 x| 12}$ & 12521 & $3 \div 8$ & $4,263,38 ?$ & 39,6640 & 44.3 .1 & 336.0 \\
\hline Ro. Koreat & 44.85 & 9 & 435.137 & $1), 700$ & 125.1 & 1351 \\
\hline Malaysia & 20.14 & 330 & $78.32 !$ & 3,890 & 74.0 & $7 \div 7$ \\
\hline Mexio & 91.83 & 1,458 & 304,596 & 3,340 & 79.7 & 72.9 \\
\hline Niw $7, z$ and & $i .60$ & 271 & 51.657 & 14,340 & 13.7 & 139 \\
\hline Nim Cinines & -4.3 & $4(1,3)$ & 4.976 & 1.160 & 2.6 & 1.4 \\
\hline 1'hilipprines & 68.59 & 300 & 71.865 & 1.050 & 17.5 & 28.2 \\
\hline Singapore & 2.99 & 0.65 & $74.83 !$ & $2(0,7,30)$ & I 18.3 & 124.5 \\
\hline Taipe: & 21.30 & (3) & 258,31 & $1=2,439$ & 111.7 & 103.6 \\
\hline Thiolanded & 58.24 & $5: 3$ & 151,630 & 2,740 & 56.5 & 70.9 \\
\hline $\mathrm{cst}$ & 263.12 & 9,809 & $7(\mathrm{~K}), 007$ & 26,980 & 583.9 & 771.3 \\
\hline
\end{tabular}

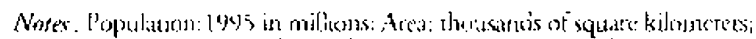

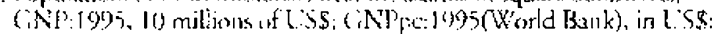

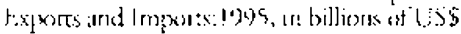

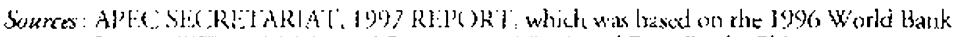

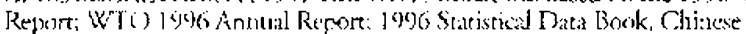

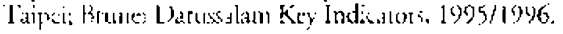

The issue of power imbalance is, indeed, teal, and emerging as a potential conflict among the member economies. Mahathir's warning should not be brushed aside simply as a nationalistic complaint with an anti-American sentmem nor should it be called "obscure," as Clinton labeled it. No once can deny that there is tension berween the instirution-building impulses of the Anglo-Saxon participants and the conscnsus-building impulses of the Asian participants in the APEC organization. There are basic differences in value orientations arnong the APEC member nations, especially between Westerners and Asians. It is difficult for the North Americans of NAFTA as well as Auscrians and New Zelanders, to understand the value orientations rooted in the traditions of East Asian societies and the different historical experiences that Asian people have gone throught. For cxample, Japan has modernized and is no longer a feudal socicty. However, "there is no doubt that the Japanese remain Japanese. Their homes are Japanese. Their souls are Japanese....their value systems, though changing, remain fundamentally" Japanese. They bow deeply and behave reverentially toward theit elders."

AlY C must find a way tor a pragmatic spirit of accommodation and consensus-build- 
ing to overcome irs diversity in size, wealth and cultural origin. As William Bodde, Jr., the first executive director of APEC has noted, the varying reactions of the APEC members to issues raised at the ministerial meetings "reveal underlying differences that will have to be worked out if APEC is to become a true Asian-Pacific economic community." It is a serious mistake if APEC members focus only on institution-building for economic integration without any concerted efforts for cultural understanding herween Fast and West. At the same time, a policy instrument has to be developed by APEC, to insure that the developing and smaller couneries can maintain economic and political autonomy.

The idea of an "Asian view," on the other hand, argues that while there are many differences among the Asian members of APEC, there are also similarities which have produced an "Asian consciousness and idcntity." Japan, the Republic of Korea, Tawan, and the original members of ASFAN (Indonesia, the Philippines, Malaysia, Singapore and Thailand) all have the recent common historical experiences of directly confronting communism. Another cultural commonality is found in the Asian view, which emphasizes that the group is the most important unit in a society with the individual's interests subordinated to the interests of the whole. "The economic dimension of the Asian view highlights the strong links between the government and business, which usually leads and strapes economic development. Another distinceive Asian feature tefers around informal and flexible "network-based" economics rooted in family tees, social relations and connections as spposed to the "firm-based" economies rooted in laws and binding contracts which are characteristics of the Wiest."

\section{The Issue of Agreement For 2010/2020 Deadline}

One of the major achievements of APFC has been the decision by the member economies to reach a total liberalization of trade and investment by 2010 for the developed member economies and by 2020 for the developing member economies. This bold agreement was reached at the Bogor Summic Meering in 1994, a meeting specifically tailored for the developing and underdeveloped economy members. Here lies a dilemma for those Asian nations, which are currently struggling with economic difficulties. I low can they attain the ambitious conomic goals they have agreed to completc by the 2020 deadline? 'The problems with this agreement are that it is not legally binding, decisions in APEC are made through consensus, and the compliance with this agreement is also voluntary.

Some leaders of Asian member economies like Mahathir of Malaysia and Japanese officials have argued for a flexible "concerted unilateral" approad to reaching APEC's liberalizarion agreement. In other words, each member could move ar its own pace according ro different levels of economic development. They argue that libcralization "should come about fundamentally through the unilateral best endeavor and action without intimida-

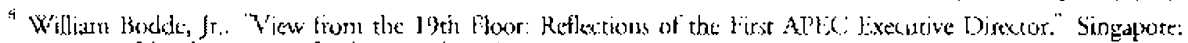
Inseicute of Southeast Asian Studicin, 1994, p.38.

Vicule G.allant and Richad Subbs, op.cis., p.li.
} 
rion" by advanced aconomies." This line of argument is certainly bothersome to the Anglo-Saxon nember economies of Al'EC. The comprehensive approach is advocated by the Linited States, Austratia and Canadit, who feel that the incerests of advanced mernhers are nor fully served and they may even consides pulling out of APEC. unless the agrements are nor followed fully. Sandra Kristoff. the U.S. Ambassador to APEC, expressed such a sentiment of the advanced nations, saying that "for many of us, to prom vide for sectoral exclusion because of domestic sensitivities would be to turn Bogor on its head and to call into scrious question the continued interest of many of us to participate."

Asian monber economies are much more contortable with loose language for flexibility rather than a uniform fixed timetable. legatly binding targets for all members, which is what the Western actuanced momber cononies are proposing. These issues were addressed at the Osaka Meering in 1995 and at the Subic Meering in 1996. Agreement was reached in Osaka that each member's plan for libcralization induding "specific concrete details" and "time frames" would be presented at the Subic Bay Meeting, At the Subic Meeting, again, the individual action plans (INS) were noc clcarly presented, and mose of them were flexily guidelines, or frameworks, for liberalizanion, which can be revisired and revised on a continuing basis by tach member economy. "NPFC. must find ways to balance different perspectives on this issue of agreement for the rotal economic liberalization deadlines of $2010 / 2020$.

\section{The Issues Of Security}

As Donald C.. Flelimann correctly points out, "although the Cold War is over, the post-Cold War interregnum srill holds two of its unique fearures that remain particularly: important for the United States and Asta. First, there has not been a multilateral military alliance like NATO in the Pacific, and bilateral arrangements with South Korea and Japan notwithstanding, regional containment was essentially supplied unilaterally by the United States." APEC faces a complex task in achioving the free and open trade and invesment wide the tariff reducion to 0 per cone by the year 2010 for the advanced countrics and by ?020 for the dereloping and anderdeveloped economics. These long term objectives can only be achieved if an environnenc of regional, and indeed global, political stability is secured. The region will need to develop a collecrive responsibility for its long-term securing ( O coursc, the complexity of the region with political and ideological differences makes the security issue very difficule to be included in APEC"s agenda. For example, Japan, China, Australia and some ASEAN nzembers are opposed.

There are three major arguments for opposition. Tirst, the sensitivity of secursty issues coukl derail the organization before it an develop. Second, security discussion deflect

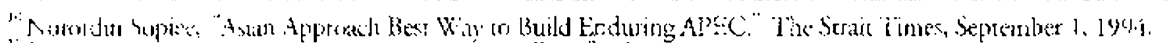

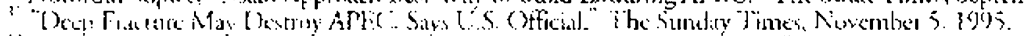

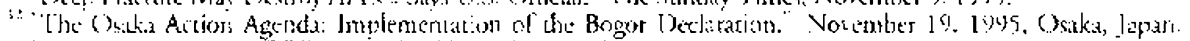

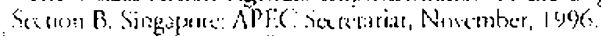

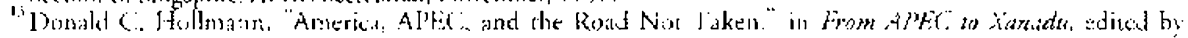

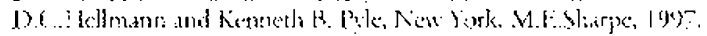


attention from the economic goals that have distinguished APEC to date, and thus hamper their implementation. Third, if APEC took up securiry issues, it would either duplicate the ASEAN Regional Forum or threaten its evolution. ${ }^{1 /}$ Yet, the issue of security arrangements by the APEC nembers must be taken seriously if the APEC's long term economic objectives are to be achieved. Ieadership in the Asian-Pacific region must realize that security is indeed an inseparable from of economic concerns. Peace without secu-rity cannot last long in the Asia-Pacific region, as nationalism is still a conspicuous feature and two major powers (Japan and (hina) in the region are not assuming their share of leadership obligations. The Pacific region has the largest armed forces in the world: China, Russia, the United States, North Kurea, Vietnan, South Konca, and Taiwan. The ccononically powerful nations will continue on build their military power, thus threaterning the "pacific" state of the region. I would argue that APEC cannot function ourside of the globat and regional security framework in this age of globalization and regionalism. Unless security issues and conflicr of interest are properly dealt with. APEC will be in grear danger of faltering as a viable international community:

We have so far discussed three major issues faced by $\mathrm{A}$ ['EC including the issues of the diversity of its member and power imbalance, the agreencent for 2010/2020, and security. There are a host of other issues faced by $\mathrm{APEC}^{2}$, such as human rights, the structural consideration, institutionalization, etc. These issues could also create setious conflict of interest anong the membet economies of Al'EC, and they should be resolved in order to establish APEC as a desirable regional community, which can contribute to the global world order. Among the 10 working units of $\mathrm{APEC}$, the human resources development programs can provide some countermeasures addressing the above-mentioned issues and conflicts.

\section{HRD PROJECTS AND NETWORKS AS THE POTENTLAL OF HRD}

APEC has ser forth scven priorities for HRD activitics. They are as follows:

(1) provision of quality basic education for all;

(2) analysis of the regional labor market on allow sound forecasting of the rends and needs in humar resources development;

(3) an increase of the supply and enhancenent of the quadity of managers, encrepreneurs, and educators/trainters in areas of the economy. which are central to the fostering of economic growth and development (these areas include training in small-and medium-sized enterprisis, entreprencurship, and marsagemen of suscaituable growl incorporating cconomic and environmental considerations):

(4) reduring deficiencies in skills and unemployment by designing industrial and other training programs for all stages of a person's development;

(5) increasing the quality of curricula, texching methods, and instructional materials;

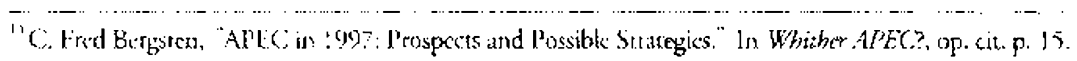


(6) increasing the opportunicies in the region for people, who scok skills required tor economic growth and development of member economies and the region as a whole;

7) preparing organizations and individuals 10 remiun productive in the face of rapid economic

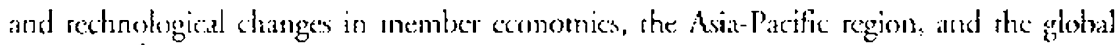
econsomy.

At the 5th Ministerial Meeting in 1993, the APEC leaders decidad to set up the HRD arorking plans to define the priorities for IIRD activities in APEC as well as establish prograns fir their implementation in the immediatc as well as longer terms. HRD's tive network groups have selectively followed the APEC's plans for HRD. The first HRI) we:work sroup mer in Manila on January 1996, and ealled upon the working group to deselop plans to analyze the regional lator market, manage and strengthen the small and medium ized entretprises, facilicate the mobiliry of persons, liberalize and facilitate trade in services, and implement execuive cducation. The rerent $H R D$ working group meetings were held in Sydney on january 20-23, 199\%, and in (hinese Taipei on June 16-19, 1998. '] 'he Second AllC. Mirnsterial Merting was hold on September 23.26, 1997 in Sooul, Korca.

At the Seoul Ministerial Mecring on HRI), it was declared thar human resources are main assets in achieving and sustaining the economic dynamism of the Asian-Pacific region. The main theme -- The Strategy for Developing Hunan Resources under a New Environment and Challenges -- was broadly discussed during the meeting and it was noted that "all member economics in APEC are dedicated to human resources development the most important resource available in the Asia Pacific Region to sustain cconomic growth and development, in the end, to improve the quality of living for the per ple of the region." "1; The acrive HiRD projects of various member countries reported at the Taipei HRD Working (itoup Meering were as follows:

\begin{tabular}{|c|c|}
\hline Australia & University Mobiline in Asia and the l'acitic (UMAal') \\
\hline Jараль & 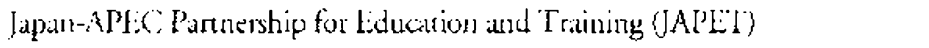 \\
\hline Kinsed & AHC. Vocational Thaining Program \\
\hline Korca & APFC Youth Skill Camp Program \\
\hline Tingapors & Proposed liramewarl for the Organizarion of the 2 nd APEC. Fducation \\
\hline & Ministetial Meeting to be held in Singapote \\
\hline Singapor: & $\begin{array}{l}\text { Updatc of AlPC Fducation Hubs and APEC Sholarship tor Study at NLSS } \\
\text { \& Nill: }\end{array}$ \\
\hline ailind & APle : Businsss Voluntes l'ogran (APCC BVP) \\
\hline
\end{tabular}

The 1998 HRI) Working (iroup Meering also endorsed the following self-funded proposals. Each proposal was classified by various networks: Business Management Network

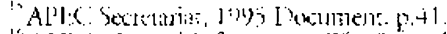

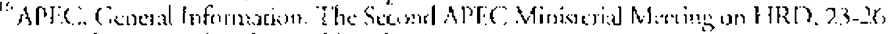

Seprember. 199?. Seoul. Repulblic uf Korea, p.21

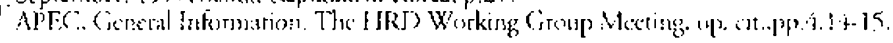


(BMN), The Fducation Forum (EdFor), Human Resources Development for Industrial Technology: (HURDIT), Labor Market Information Group(LMI), Network for Economic Development (NEDM).

\begin{tabular}{|c|c|}
\hline Australia & Mutual Recognition of Qualification State lII(Enginecring) (kAtFor) \\
\hline \multirow[t]{2}{*}{ Canladis } & Best Practices Workshop on School to Work Transition in APEC Mcrnber \\
\hline & Fconomics for Youth at Greatest Risk of Unemployment (FdFor/HURDIT) \\
\hline Japan & Alternative Dispute Resolution Executive Fducation Project(BMN) \\
\hline \multirow[t]{2}{*}{ Japan } & APEC White-Collar Training Program on Production and Material \\
\hline & Handling Management under the Total Management System(BMN/HRDI' 1 ) \\
\hline \multirow[t]{2}{*}{ Japan } & Cross-Member Seminar on Social Development and Human Resources \\
\hline & Development in the APEC Member Feonomies (NEDM) \\
\hline Korea & APEC Youth Skill Camp Program (HURDTT) \\
\hline \multirow[t]{2}{*}{ Korea } & Cross-Cultural Comparisnn on Open-Learning Suystem in APEC member \\
\hline & Economies (EdFor) \\
\hline \multirow[t]{2}{*}{ Korea } & Exchange of Education Professional Among APEC Member \\
\hline & Economies(EdFor) \\
\hline \multirow[t]{2}{*}{ New Zealand } & Workshop on Work Based Education and Training Reconsidering the \\
\hline & Rok of Government(NEI)M \\
\hline Chinese Taipei & Ficonomic Restrucrutring and Iabour Market Dynamics(NEDM) \\
\hline USAVChina & Achieving High Performing Schools (EdFor) \\
\hline
\end{tabular}

The Working Group and Nerworks reviewed, assessed, endorsed and ranked new project proposals according to the process agreed upon at the $17 \mathrm{th}$ Mecting in Bali. The following proposals were endorsed, for APEC Central funding with the rankings as indicated:"

Of all the above projects and other unreported projects currently in operacion and be implemented in the future, the five networks of projects may provide some counrermeasures for the issues faced by AlPC. "They are The Education Forum (EdFor), Business Managcment Networks (BMN), Human Resources Development for Industrial Technology (HLRDM), Labor Market Information Group (L.MI), and Necwork for Economic Development Management (VEDM). These networks have the potential for providing countermeasures to reduce the issues and conflicts of APEC, and eventually to bring economic development in the Asian-Pacific region. The Education Forum has the greatest potential for providing such countermeasures.

\footnotetext{
"AlEC, The 15th Moxting of the Al'HC Working Group on Human Resources Development. Chinese T"aipei. lune $!(3,-19,1998$, pg.1:-1/3.
} 


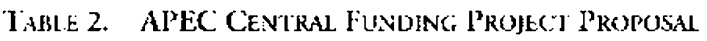

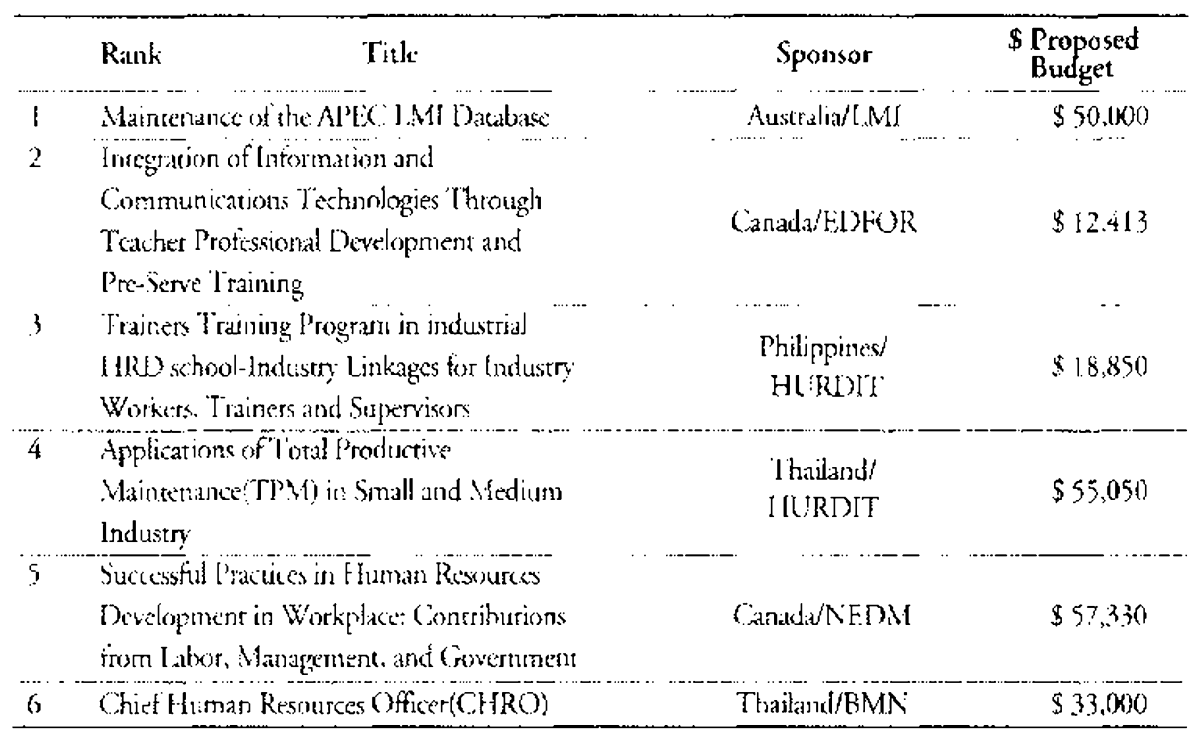

Network Project Phase II

The Wirking Coroup Erodorsed the following for New Project Proposals for TIIF funding

\begin{tabular}{|c|c|c|c|}
\hline Rank & Title & Sponsor & Fund Soughe \\
\hline \multirow[t]{3}{*}{1} & AJ'EC Fxpers-T Tainers-Excessives & philippines'japas & \\
\hline & Wutbshop on Interaarion Qualing & B.MN & $\$ 123,982$ \\
\hline & Asslizaurce Systems & & \\
\hline
\end{tabular}

\section{The Potential of The Education Forum (EdFor)}

'The report of the Task Force on the Human Resources and Social Impacts of the Financial Crisis was discussed at the 12 th Meeting of the the Edfor. In terms of potential deliverable for 1998, the EdFor identifed several specific projects which could enhance some mutual understatuding and cooperation to teduce conflice based on diversity of membership. They are as follows:

(1) We are $A P E C$

(2) APEC. Regiond Education Hubs

(3) Crilization of Computer Network in Scheos

(4) Projecrs on Monituring of School Performance

(5) Best Priktices Workshop on School so Work Transitions in APEC Member

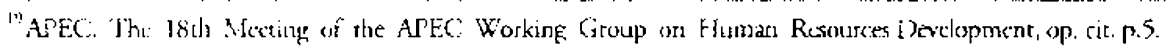


Economies for Youth ar (irearest Risk of Unemploynent

(6) Improving and Expanding Edtuation Stacistics (l'hase ll) Project

(7) Mutula Recognirion of Qualification. State Il-Fngincering

Of the various HRD's EdFor programs, APEC. I eaders' Education Initiative (AL.FI, hereafter) seerns to be the best way to provide sone countermeasures for the issues we have discussed so far: Proposed by the United States, ALEI will develop regional cooperation in higher education, study key regional econornic issues, improve workers' skills, and facilitate cultural and intellectual exchange. ALEl's mission is to foster understanding of diversity in this region, and to direct other regional cooperative efforts in education and human tesources development toward a better understanding of open regionalism and security issutes such as the regional and global imperative of the new workd order. AI.EI is dosely linked to the APEC Fducation Foundation.

The purpose of the AJ'EC. Education Foundation was to advance the cause of educarion and human resources devclopment. As an important part of the practical implementation of AIEI, it wil channel investments into the development of the human tesources in the region. The APEC Educarion Foundation plans to establish a financial resource base which would permit it to carry out exchange programs and research and development in addition to maintaining a dacabase on HRD-related activities and institutions.

At the present time, another important HRD education project called APEC EduNet is being developed at the Center for APEC Studies at the University of Washington. The objectives of the APEC. EduNet are,

(1) to tighty integrate the $A P E C$ EduNer Internet Suite with individual PC desktops, giving users a comenon platform for joint work on international projects:

(2) wo stablish multiple points of presence for APEC EduNet application servers in order to improve access for users in APEC member countirie;

(3) to secure projects and individual communications from unauthorized access; and

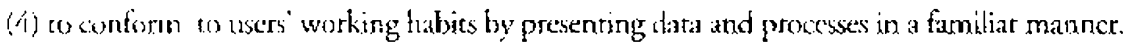

"Ihe LduNer was endorsed at the Osaka Ministerial Meeting held in 1995 and it was laumched during a 15-ninute mulrimedia event at the Manila Ministerial Meeting in 1996. As the APEC. EduNet matures in the next several years, it will be well positioned to levefage the exponential growth of the internet throughout the eighteen APEC member connomics. Through the usc of EduNict, the websitc of the networks and working groups, the HRH programs for Lifor will be revitalized for effective application ao connrermeasures for maior issucs of APEC such as diversity open regionalism. the agreement of $2010 / 2020$, and security:

The question is then how can the HRD's EdFor projects, including ALEI, Educational Foundation and fiduNet, provide counternedsures for the issues and conflicts? 'These HRD halfor programs cannor bring about immediate countermeasures and settement to the issues. It may ${ }^{\circ}$, however, expected that various HRD cducational projects may result in the alleviarion of those issues of APEC. There are several other FIRI) educational 
projects. which are conducted by the HRD Working (iroups. ALEI, for instance, attempts to establists APEC. Study Centers in all the APEC. member countries in order to promote collaborative researct on APEC related issues. APEC's Executive Fducation and Development stresses the development of human resources within the region so that the excoutives and managers can understand the emetging trends and realities in the AIPEC. region. "20 Through Industrial Technology Education. HRD Working Group tries to improve the quality of curricula, teaching methods, and instructional materials related on industrial technology Critical aspects of this program inctude cooperative efforts geared coward exchanges of information on training and skills, development policies, stratcgics, and programs, among nember economits. I. ifelong leatning programs also atempe to improve labor productivity and flexibilicy for sustainable and equitable economic growth in the AI'FC. rezgion. This program emphasizes the significance of creating new approaches and HRI) programs for application in all stages of a persoris career. Information exchanges through Edu. Vet will be very important for providing alternative channels of communication when confronted with conflicts. Efective and efficient communication of FIRI activities to a wide range of audiences within the APEC member conomies will certainly enhance mutual understanding and cooperative efforts. For instance, the website of each network and working groups of HRD may provide the neccssary information for obtaining HRD Working (iroup publications for their project reporss. "Communicating for Results" seems $\mathrm{t}(\mathrm{b}$ be the most vital part of reducing misurderstanding and conflicts amung the member econonies of AlLC.

As strown in the country reports at the Chincse lajpci HRD Working Mceting, the most active IIRD projects are almose entitely in the arca of EdFor Network, especially Australia's University Mobility in Asia and the Pacifx. Japan's APEC parnership for Fducation and Training. Korea's AlEC Vocational Training Program, and Singapore's APEC Scholarship for Study at NSU and N1W. Among the 11 propsed HRD's self funded projects, 5 are in the area of Edlor Nerwark. "I hus, Eafor Nework, indeed, has greal potonial on adede the issucs and conflicts faced by AI'EC through various education and training projects.

\section{The Potential of HRD's Other Networks and Task Force on Human Resources, and the Social Impact of the Financial Crisis}

HARD's Newworks on Business Management (BMN), Labor Market Information (LMI) and Human Resource Development for Industrial Iechnology (HURDJT) and Fconomic Ixvelopnent Management (NEIDM) are all dosely related to the Task Force on Human Resoure and Social Impacts of the Financial (Crisis (HRSIFC). The 18 th Meeting on HRI) Working (Group of APEC endorsed the following specific recommendations for the ' lask Force on HRSIHC:

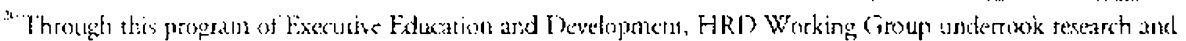

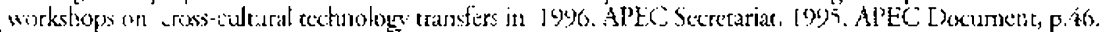

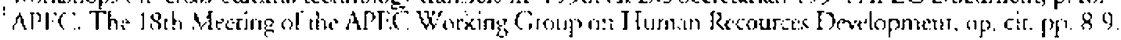


1. A project which examines the best practices of member economies in balancing market liberalization with labor market adjustment policics to respond to external shocks.

2. A study which emphasizes the importance of stenglening the dissemination of HRD Working Group projocts, as well as undertaking periodic stock-taking so that the Working Group will become an ongoing source of informarion on the best practices.

3. The HRI Working Group will contribute to the efforts of APEC. Finance Ministers to strengthen corporate governance in genetal, ind tinancial sector supervision and regulation in particular, in the region. in ordet to support training programs as appropriate.

4. The IIRO WG contribute to the Economic Commitces project to exanine the inupact of trade liberalization by undercaking specific analyses of human reseurces and its social impact.

5. Internatiental finamcial institutions and privare sector investors can contribute much towirds alleviaring adverse human resources and rhe social impacis of the financial crisis.

6. The private sector should play a central role in the econonnic recovery of the region, and the IfRD Working Group should develop stronger links with key private sector stockholders: induding business, labor, women, youth and non-governmental organizations, to enable them to wntribute lowarl the Working Group's accivities.

7. The active participation of addiaional member etonomies in its aclivities, recognizing that the impace of the crisis goes swell beyond the first-hit conomics.

The Task Force on HRSIFC clearly recognized a sudden reversaf in economic fortunes, rising unemployment and underemployment. declining real wages, the impact this has had on women and, limited social safecy nets. In relation to the Labor Market Responses, the Task Force sec up scveral common themes: integrated strategies; labor market information and analysis; short-term relicf mcasures; social safety nets; retraining, participation and cooperation among sectoral stake-holders; improved working arrangement: and in particular, support for export sectors. With such common thenes, the Task Force set up the following four objectives:

texplore human and labor matket impact

Extmate the likely degne of rentructuring required in labor markets

- Identity and shate knowledge and especially for the "best practices"

- Recommend appropriate and realistic action to the HRD Working Group

The activities of the lask Force in relation ta various HRD nerworks of economic concerns has great potcntial for reducing conflicts facing APEC such as the imbalance of coonomic power among diverse nnember conomics, open regionalism, and free-tariff deadline of $2010 / 2020$. Moreover, the future activities of the Task Force certainly tas the potenrial for alleviating the financial crisis faced by most of the Asian member economies of APFC.

\section{The Potential of the Project on Small and Medium Enterprises}

Another of HRD project. which carn provide counermeasures for the issues and con- 
flicts of APEC is the program for small-and medium-sized enterprises (SMEs). At the 1904 APEC: Ministers Mecting in lakarca it was agreed that SMEs policy dialogue on human tewoures devetopment, information access, technology sharing, the availability of finance. and marker access, should be further enhanced. Subsequently, the AP'BC's HRD Woking Group has adoped SMEs as a key in the workplan. Since SMEs are extremely imporant sectors in all of the developing and underdeveloped member economies of APLC, this issue can provide the countcrmeasures necessary to deal with the issues of diversity and power imbalance.

In order of maximize growth opportunities and enhance the competitiveness of APEC, menter economics, the HRD Working Crroup pursurd many other projects that could promote the quality of management and entrepreneurial skills in human resources. For example, at cross-neturork Symposium on HRD for SMEs, a Symposium on Marketing Stategy For SMEs, 'liaining Programs and Surveys To Enhance Productivity Among s.Mls, and orher projects tor small and medium size companies were conducted in the past and will concinue in che fututc. These programs all promoti linkages and informa. tion exchanges on research and development along with the promorion of on the-job training from mid to long-term.

One area where SME development is clearly beneficiat is the development of a thriving local supporting indusry. it could increase local procurement, increase local manufacturing and service sector capacity, and enhance the future comperitiveness of developing cconomics. "It is, thus, a wir-win situation for all concemed."

Close nopecalion baween large enterprise and SMFs could crable SMEs in developing conomies to benefir from traming in new tedinologies offerd by SMF in devel. oped economies. At the same rime, SMEs in developed econemies can benctit from the additional manpower that such coopcration oflers.

More specifically; the $H R D$ activity for $S M E$ was tealized by the project of $A P E C$ CINIIR FOR IECHNOLOCY EXOLANGI AND TRAINING FOR SMES (ACllelSME). The (anter started "to perform the role of a resource center with discinct capabilities in information nerworking, mobilization of training opportuntics for tcehnical know-how absorptions and upgrading, and organizing specialized activities to reach out ro SMFs for syndicating rechnology transter projects in the spirit of ineraregional cooperation and business intemationalization."

[here are onter FIRI) prograns which could provide countermeasures for the conflicts facod by APLC: Infrastructure Development, Strutural Adjustment Policics, and Bcst-

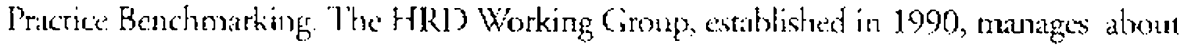
70 projects, which all promote beticr communication and ooperation among the A PFC member economics. In one way or anotber, these projecrs have the potential to provide conterme:sures for the conflicts APEC faces. Ministers at the 1997 Vancouver Meeting welcomed the results of the UIRD Ministerial Mecting held in September 1997 in Seoul. They emphasized that lifi-long learning and school-to-work transitions atc

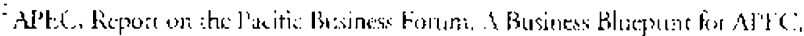


essential to create an adaptable workforce as well as to provide individuals with relevant skills; and that developing skills is one of the most important means for adjusting to the changes in the labor market and the broader economic environment. ${ }^{\text {is }}$

\section{CONCLUSION}

More than other units of APEC. HRD with its various projects, programs and lask Force activities, has great potential to provide some coustermeasures for alleviating the conflicas faced by AlPEC. Fispecially, HRI)'s Network for Education Forum (EdFor) with various projeces such as AFLI, EduNet, Youth Vocarional Training may be able to generate mucual understanding through effective communication of informations and exchange of ideas and skills. The 18 th Meeting of the APSCC Working Group on Human Resources Development has launched and urged the HRD Working Group to continuc working for lask Force on Human Resource and Social Impacts of the Financial Crisis in 1999. The Task Force along with various HRD's. Networks on industrial and economic development (Business Management Network, Human Resource Development for lndustrial Technology, Labor Market Information. Network for Economic Development) indeod has the great potential to make significant contributions to the economic cooperation among the member economies in the Asian-Pacific region.

It is difficult to nake any concrete and specific policy proposals for directly linking the HRD programs to countermeasures for the issues of APEC. However, the HRD programs and projeces should be coordinated with specific objectives for alleviating the issues and conflicts faced by APEC.

The commorn policy concepts will essentially consist of basic principles for cooperative action to create mutual understanding of diverse culcures and to minimize the power imbalance among the APEC member economies. HRD' projects under "Cross Cultural Management" (Priority 3), which is one of the Fight Priorities, should emphasize cross culturad cooperation. Joint cooperative activitics shall be developed to promote the complete liberalization of trade and jnvesument with different timetables for each member economy according to the lcvel of devdopnent and economic capacity. Moreover, the HRD Working (iroup and other HRD fora should develop a system for continuous review and assessment on security issues in relation to the possible threat of war and regrional contlict in the Asian-l'acific region. APEC will work more effectively for the social economic development in the Asian-Pacific region, if and when the issues and conflices faced by APSC are alleriated through the cooperative activitios of the vartous units of APEC, especially through the Hutnan Resources Development Unir.

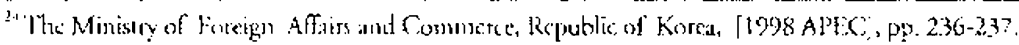




\section{REFERENCES}

Asia-Pacitic Konomic Cooperition. 1993. "A Vision for APEC: Towards an Asja Pacific Economic Community." Report at the Eminent Persons Group to APEC Ministers compiled by the APEC: Secretariat. Singapore, October.

Asia-lacific ficonomic Cooperation. 1994a. "Manda Action I'lan for AJEC (MAPA)." Repon compiled by the APF:C. Secrerariat. Singapore. Noxember.

Asia-Patific Econumic Cooperation. 1994b. "Report on the lacific Business Forum: A Blueprint for Al't.:" Report compiled by the APEC Secretariat. Singakore, Ocaber.

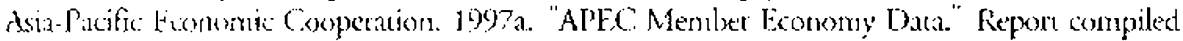
by the APFC. Secrecariar. Singapore.

Asia-l'acitic Economic Cooperarion. 1997b. "Moming Session of the Vancouver Economic teaders Mvering." Surmary cumpiled by the ALEC Secredariat. Singapore.

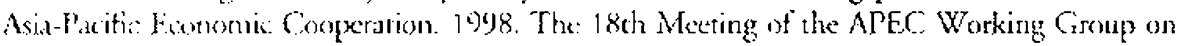

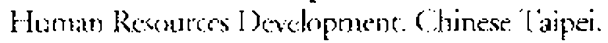

Bergaten. (.. Fied. 1997a. "()pen Regionalism." It Whither APEC. The Progress to Date and

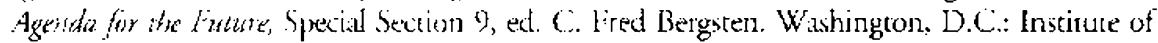
Intemational Ficomomics.

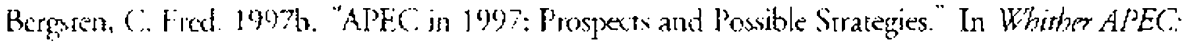
The Progreis s" Oate and Agenda for the Future. Special Section 9, ed. C. Fred Betgsten. Washington, D.C.: Insticute of International Eionomics.

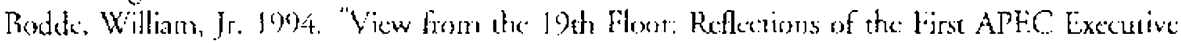
Dilecto:" A Cencral Secretary Repure compiled by the Insriture of Sontheast Asian Sudies. Singapore.

Gallain, Nicok, and Richad Stubis. 1997. "Al'EC's dilemnas: Institution-Building around the I'mitic Rin." latcifi Affors 70(2): $203 \cdot 218$.

Ha, Yong Chod, and Tathyun Kim. 1997. "Rctlections on APEC: A Korcan View." In from

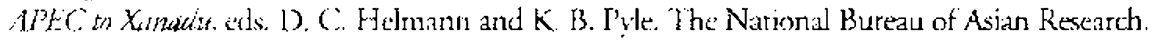
Vew York: M. 1.. Sharpe:

I Tollmann, [7onald C. 1997. "Anerios, APEC, und the Rodd Not Taken: International leadership in the Post-Cold War Interregnum in the Asia-Pacific." In Fram APlC to Xanadai eds. D. C. Helmann and $K$. B. Pyle. New York: M. E. Sharpe.

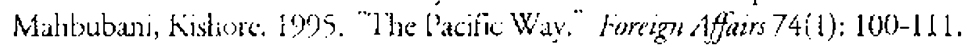

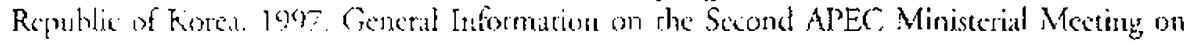
Human kesources [Devalopment. Sroul: Korea.

Sopiece. Norondim. 1944. "Asian Approach: Bes: Way to Build Fnduring APEC." The Sumday Tïns, Norember 5.

Yoo, fang-Hec. 1'97\%. "Membership and P'articiparion in APl:C." In Whiter APEC: The Progress to bats and Agenda for the Fiture. ed. C.. Fred Bergsten. Washington, D.C.: Institute of Interational Eomomis's. 